\title{
Same Task, Different Activities: Issues of Investment, Identity, and Use of Strategy
}

\section{Susan Parks}

\begin{abstract}
Drawing on activity theory and the construct of investment, this article explores how three francophone CEGEP students variously invested in a task that involved producing short documentary-style videos in English. Case study data included interviews with the students and teacher and student work portfolios. The analysis suggests that the appropriation of, or resistance to, particular strategies was related to the construct of motive and issues of identity. Although all three participants had a positive orientation to L2 language learning, differences surfaced about the value attached to classroom language learning, task preference, and attitude to group work. The author argues for task-based research that takes into account the sociocultural dimension of task performance and learner's perspective, as well as studies that involve a broader range of tasks than is currently the case in traditional SLA task-based research. Implications of the study for ESL teaching are discussed.
\end{abstract}

Although in the field of second-language acquisition (SLA) task has been identified as a relevant unit of analysis, much of the research to date has focused on the role of task features and task implementation (Chaudron, 1988; Crookes \& Gass, 1993; Skehan, 1998). In a recent review article Skehan (1998), commenting on the direction of future research, underscored the need for studies conducted in actual classrooms, noting that to date most have involved cross-sectional research designs "predicated on the assumption of quickly detectable effects." However, Mohan and Smith (1992), in a critique of SLA conceptions of task, voice a more fundamental concern: the role of social context and how it may mediate the way tasks are accomplished. Indeed, the importance of examining tasks in real classroom settings has been underscored by a recent study by Foster (1998). In contrast to experimental studies, which have focused on the negotiation of input, Foster observed that when given the opportunity to engage in the types of interaction tasks typically used in such research, her students made few conversational adjustments. Foster explained this reluctance to negotiate input in sociolinguistic terms: like native speakers the L2 learners appeared to adopt the more socially acceptable face-saving strategy of pretending to understand while awaiting a future occasion to clarify the difficulties encountered.

Also of note is that SLA task-based research has tended to focus on a narrow range of tasks, frequently oral interaction tasks of limited scope. 
Research involving more substantive tasks, such as projects, has been lacking although many L2 teachers engage students in such activities. A final concern is the lack of exploration of how learners perceive the tasks they are asked to perform and how these perceptions may relate to task investment. This lack of attention to learners' perspective is at least in part due to the use of experimental research procedures, which typically involve tasks designed for research purposes rather than those found in regularly scheduled classroom activities. As well, task-based research, situated in psycholinguistic and cognitive research paradigms, has tended to value the sole analysis of linguistic data.

In this article I address the issue of investment in the context of a task where students were engaged in producing videos for an ESP course aimed at tourism students in a Montreal Collège d'enseignement général et professionnel (CEGEP). ${ }^{1}$ Drawing on my case study of three participants, I argue that learner perspective is important in attempting to clarify the differences in processes and products that emerged as students engaged in the video task. I further demonstrate how such differences may be accounted for by drawing on two socioculturally oriented frameworks: Vygotskian inspired activity theory and Norton (1997) and Peirce's (1995) notion of investment. I start by situating the study with respect to relevant theory and research, then briefly outline the methodology used to carry it out. The main focus is the discussion of the three case study participants, first in terms of descriptive accounts, then in relation to theoretical issues and the implications for teaching.

\section{Task and Task Investment: Theoretical Considerations}

Although Vygotsky has been duly acknowledged for his theories on cognition and learning in a cultural-historical perspective, the cultural dimension has tended to be obscured by research designs focusing on dyads in experimental settings. Responding to this critique, Wertsch (1985) suggested that the notion of activity as developed by Vygotsky's colleagues, notably Leont'ev, ${ }^{2}$ provides a more constructive lens through which to view sociocultural influences. In this theoretical framework, referred to as activity theory, activity is taken as the unit of analysis and is analyzed as a three-tiered construct. Thus at the highest level, activity-which refers to any human activity in a specific social setting-is intrinsically linked to motive, the individual's underlying purpose for engaging in the activity. At the second level of analysis, activity and motive are further conceptualized as actions and goals respectively. Goals serve to operationalize motives into more specific objectives. Actions refer to the specific mediational means or strategies used to achieve a goal. Finally, at the third level of analysis, actions and goals are analyzed into operations and the particular circumstances or material conditions under which they are actualized. Whereas actions and 
goals are associated with conscious goal-directed behavior, operations pertain to the more automated modes of behavioral functioning.

In contrast to the notion of task as conceptualized in the psycholinguistic and cognitive SLA literature, activity theory provides for an interpretive framework where learner perspective ${ }^{3}$ in regard to motive can be more finely analyzed in relation to processes and outcomes. The importance of accounting for learner perspective has also been signalled by critics of positivistic research paradigms, who have challenged the assumption of task as a unitary fixed construct (Coughlin \& Duff, 1994; Newman, Griffin \& Cole, 1989; Roebuck, 1998). In this regard, of particular relevance to the present study is the distinction made by Coughlin and Duff between task as "behavioral blueprint" and task as "activity," process and outcome in its sociocultural context. In their discussion of how ESL students performed on an oral elicitation task involving a picture as a prompt, Coughlin and Duff revealed how factors related to the students' personal history and the conditions pertaining to the test session itself differentially changed the nature of the task-the behavioral blueprint-as originally conceived by the researchers.

Although the issue of investment in L2 classroom tasks from an activity theory perspective has seldom been addressed, a study by Gillette (1994) involving students enrolled in a French course in a United States university is of particular relevance to the present discussion. In her study Gillette argued that the way students invested in the course was related to their initial motive for registering in it (i.e., genuine interest in learning French or the obligation to fulfill a course requirement). Drawing on a case study of six participants, Gillette attributed the positive orientation of the three effective learners to their personal histories and life experiences, which had made them aware of the "use value" of learning languages; by contrast, the three ineffective learners had no such experiences on which to draw. Gillette further observed that those learners who had a positive orientation to the course tended to use effective language learning strategies, whereas those who had a negative orientation proved ineffective in their use of strategies even when instruction in effective strategy use had been given. In view of the way the use of effective language learning strategies appeared to function as a means to an end (i.e., were a consequence of learners' initial interest in language learning), Gillette challenged the belief implicit in much of the literature on learner strategies that effective strategies alone constitute an explanation of $\mathrm{L} 2$ achievement and individual differences.

Although Norton's (1997) notion of investment (Peirce, 1995) has evolved separately from activity theory, the research associated with this construct, generally conducted using qualitative data-gathering procedures, provides interesting insights into the complex nature of L2 language learner engagement in specific social settings, including the classroom. In elaborating her 
notion of investment, Norton (1977) notes that motivation as typically conceived in SLA research tends to place the onus on the individual L2 learner for seeking contact with L1 speakers (and access to input). By contrast, the notion of investment, influenced notably by feminist poststructural traditions, draws attention to issues of agency and the learner's sense of identity:

I have used the term investment to signal the socially and historically constructed relationship of learners to the target language and their sometimes ambivalent desire to learn and practice it... The construct of investment conceives of the language learner as having a complex history and multiple desires. An investment in the target language is also an investment in a learner's own social identity, which changes across time and space. (p. 411)

In this perspective, the individual's sense of self or subjectivity, viewed as a site of struggle, may be negotiated and renegotiated in response to the provisions and constraints of particular sociocultural contexts.

In contrast to the Gillette (1994) study, which showed a strong relationship between initial motive (in terms of understanding the use value of L2 learning) and investment in a language course, a study by McKay and Wong (1996) involving immigrant Chinese students in a mainstream US high school, is less clear cut. In the context of the ESL courses students took at this school, McKay and Wong demonstrated how their investment (or lack of investment) in school tasks was tied to their need to create viable identities for themselves. In discussing the case of an immigrant Vietnamese woman who dropped her ESL course despite a desire to learn English, Norton (1997) underscores how issues of identity have important consequences for positive and productive language learning and teaching. Other studies conducted in diverse social settings (Angélil-Carter, 1997; Goldstein, 1997; Maguire, 1997; Thesen, 1997) provide further evidence of learners' subjectivities as sites of struggle with varying implications for language learning.

By emphasizing the sociocultural aspects of language learning, proponents of both investment and Vygotskian-inspired theories tend to argue for more nuanced depictions of language learners than has at times been the case in much of the SLA literature. From the perspective of investment theory, McKay and Wong (1996) note that the portrayal of the learner as a complex social being stands in marked contrast to "the kind of generic, ahistorical 'stick figure' of the learner painted in much literature on second-language learning and many teacher training programs" (p. 603). Similarly, in regard to activity theory, Lantolf and Pavlenko (1998) have stressed the need to construct "whole learners," which takes into account the situated nature of language learning as well as the individual's personal history. 


\section{The Study: Setting and Methodology}

The case study data discussed here were drawn from a qualitative study conducted at the Institut de tourisme et d'hôtellerie du Québec, a franocophone CEGEP in Montreal. As this CEGEP specializes in training students for the tourism, hotel, and restaurant industries, most of them move directly into the job market rather than going on to university. In view of the practical orientation of the students and the nature of the targeted professions, the teaching of second languages, especially English, is considered by both the language instructors and the administration as an important component of the curriculum. Participants in the study were all involved in the tourism option. Before taking the intermediate-level ESP course, the focus of the study, participants had completed a general ESL course. The instructor of the ESP course, Diana Bruno, ${ }^{5}$ had worked at this CEGEP for over 20 years.

As an ESL instructor who has always been interested in finding innovative ways to teach, Ms. Bruno decided to set up a video project to provide for an integration of what she referred to, in reference to the Quebec Ministry program, as "disparate objectives." The video project, which required pairs of students to produce in English a 5- to 7-minute documentary-style video of a tourism site, enabled students to draw on their disciplinary knowledge. In the general tourism program, discussion of and visits to sites, viewing of videos and slides related to tourism, and instruction in how to conduct guided tours are important pedagogical activities. Although prior to taking Ms. Bruno's course none of the students had ever made a video, the school provided videotaping and editing equipment and a technician who could help both staff and students with production. To complete the project, which spanned the entire semester, students had to complete the following:

1. identify a tourist site of interest;

2. hand in a proposal to the teacher for feedback;

3. do research (e.g., get documentation about the attraction, make contacts and get permission to film if necessary, conduct interviews, visit the site);

4. hand in a script and storyboard (mapping out of text and images) to the teacher for feedback;

5. film the video;

6. edit the video with the technician's help;

7. revise the script in function of images (as necessary);

8. practice the voice-over with a monitor or the instructor;

9. record the voice-over (both partners);

10. present the video to classmates.

As originally designed the task provided for scaffolding at various points, notably in terms of help from peers, the monitor, and the instructor. When feedback was given on the proposal and script, students were to revise and 
resubmit their work. In-class instruction also included discussion of commercially prepared tourist videos.

Qualitative data collection procedures (Merriam, 1988) included formal and informal interviews with the instructor, in-depth interviews with students, and the collection of documents (e.g., the instructor's handouts; the student-produced videos; and students' portfolios where they kept all work pertaining to the project, notably documentation sources, drafts, and process logs). During the interviews students were asked to discuss their projects while referring to drafts and other documents in their portfolios. All interviews were recorded and transcribed. Data were gathered from two classes taught by Ms. Bruno. A total of 25 students were interviewed either alone or with their partners; as students worked in pairs this number accounted for representatives from most of the video projects. My collection of the data was facilitated by the fact that I had previously worked at this CEGEP as a colleague of Ms. Bruno.

As the data collection proceeded, task investment emerged as an issue. For the purposes of this article I focus on three students (Annie, Julie, and Stéphanie) whose interviews provided divergent portraits of how and why they invested or failed to invest in the video project. During the preparation of this article, Ms. Bruno had the opportunity to comment on my interpretation of the data. Especially with respect to Annie and Stéphanie, she had at times wondered "where they were coming from." As a teacher she considered that the interviews provided insights into aspects of these students' functioning to which she would otherwise not have had access. Taken together the three cases highlight the complexity of how students' past experiences, beliefs, and desires may mediate school tasks. As texts the interviews are further viewed as a resource for the display of self and identity (AngélilCarter, 1997; Schiffrin, 1996).

\section{A Case Study of Three Language Learners}

As illustrated below, although all participants had generally positive orientations to learning English, the way they invested in the video project varied.

Case 1 Annie: Task and negative view of classroom language learning.

Annie considered learning English important not only for her future profession in the tourism industry, but also for travel, even expressing in this regard a more integrative perspective: "C'est important que si tu voyages d'entrer dans la culture des gens" (it's important if you travel to enter into people's culture). The previous summer Annie had been to western Canada where she had practiced English while working in a resort and during her travels. In Montreal she also had English-speaking friends. However, despite this positive orientation to language learning, unlike the participants in Gillette's (1994) study, she did not invest in classroom activities such as to optimize her opportunities for language learning. Specifically, Annie did not 
perceive the video project to be of any value in terms of helping her learn English, which was further reflected in how she went about doing the task. In this regard, as Annie pointed out, what predominated in her and her partner Véronique's decision-making was efficiency-getting the job done. Tasks related to the project were divided based on who appeared to have the greatest ease in accomplishing them; in the transcript the word that recurred in French was facilité-who had le plus de facilité. Accordingly, because Annie was deemed the better writer, she wrote the proposal and the script. Veronique, who had some experience in videotaping, took charge of the filming and editing; as her English was better, she also did all the voice-over (even though both partners were required to do this).

Annie wrote both the proposal and the script in French. Although she then tried to translate them into English "un peu" (a little), most of this was done by two bilingual friends. Although she was asked to revise her proposal, she did not; as the proposal served only to tell the instructor what they wanted to do and had nothing to do with the video script per se, she considered revising it "une perte de temps" (a waste of time):

[referring to the proposal] Dans ce texte-là c'est fait plus pour savoir nos idées ... ça donne rien à réécrire quand on ne dit pas la même chose dans la vidéo, c'est qu'on avait déjà une charge de travail, c'est long quand-même, on $n^{\prime} e s t$ pas bilingue, si on était bilingue, si on était bilingue ce serait simple. (In that text it's more for our ideas, it's useless rewriting when we don't say the same thing in the video, we've already got a lot of work, anyway it's long, we're not bilingual, if we were bilingual it would be easy).

When asked whether the translation of her text had helped her in any way, she replied that she could not even remember what was in it, adding "Vous comprenez, c'est pas ça qui va m'aider avec mon anglais" (You understand it's not that that's going to help me with my English). When reminded that the voice-over might at least have been useful in helping her with her pronunciation, Annie pointed out that at the time this had not occurred to her, as the only thing she was thinking about was who was best for the job: "qui a le plus de facilité." As for the class presentation of the video, Annie acknowledged that she had simply memorized the part Véronique had written for her. When asked if any students had addressed questions to her, she replied they had not, adding "une chance ... je sais pas ce quej'aurais répondu" (lucky for me ... I don't know what I would have answered). Reflecting further she recalled that memorizing presentations was a carry-over from high school. Indeed, in this regard what stood out in her mind was how ill at ease she and her classmates had felt doing such presentations in front of each other: "tout le monde était souvent trop gênés" (everybody was often too self-conscious). ${ }^{6}$

Although Annie did not view the video project positively, what further emerged was a more far-reaching orientation to classroom language learn- 
ing, namely, that in the classroom little could be achieved. As a child Annie had lived in a village where she had not had the chance to speak English. At school her teachers, who were all francophone, did speak some English in the classroom, but she felt too much time was spent on reading, writing, and listening. Annie felt that the type of teaching she had experienced in school had not enabled her to learn to communicate in English. The fact that when she came to CEGEP she tested among the weakest students (elementary level) appeared to confirm this.

Indeed, one aspect of her school experiences learning English that she particularly disliked was having to speak English to other francophones. This concern is reflected in the following comments where she again discusses oral presentations:

Mais j'aime pas à parler en avant, surtout pas en anglais, mais j'aime ça, ça ne me dérange pas de parler en français, mais en anglais avec du monde que je ne connais pas, je ne parlerai pas; c'est juste mes amis anglais qui m'entendent parler en anglais avec eux autres.... (in class) jamais, je ne suis pas capable, $j^{\prime}$ ai un bloc. (But I don't like speaking up front, especially in English, but I don't like that, I don't mind speaking in French, but in English with people I don't know, I won't speak, it's just my English friends who hear me speak in English, with them ... [in class] never, I'm not able to, I have a block.)

In the above comments, the discomfort (gêne, self-consciousness, blocked feeling) that characterizes Annie's in-class interaction in the presence of other francophones stands in marked contrast to her willingness to speak with anglophones outside of class.

In Annie's words, what helped to unblock her English and help her realize that she could communicate in English was the immersion experience in western Canada where she was in an English-language environment:

C'est là où j'ai commencé ... j'ai appris beaucoup là, ça m'a fait comme partir, avant j'avais juste des cours dans la classe et des cours dans la classe tu parles pas, alors rendu là-bas, c'est comme je me rappelais toutes mes affaires qu'on avait appris en classe, je travaillais avec des employeurs anglais, puis je n'avais le choix que de parler en anglais, eux autres ne savent pas parler le français làbas; on est pas mal meilleur en anglais ici que les autres peuvent l'être en français là-bas, ils savent souvent merci et bonjour, c'est à peu près tout. (It's there that I began ... I learned a lot there, it set me off so to speak, before I just had courses in class and in class you don't speak, however, out there, it's as if I could remember everything I had learned in class, I was working with English employers, so I had no choice but to speak English; they don't know how to speak French out there, often they only know merci and bonjour, that's about all.) 
Comments such as these suggest that for Annie true L2 competence could only take place outside of class with speakers of English; indeed, if classroom learning had a purpose it was more in terms of amassing facts about language that could be activated in an authentic communicative context. The interview further revealed that Annie's views on classroom language learning were not limited to English. Referring to the Spanish courses she was taking, Annie anticipated that the immersion abroad that she was planning for the summer would similarly serve to unblock her Spanish: "ça va me débloquer ... c'est juste ça qui aide ... c'est le seul moyen d'apprendre une langue je pense" (it's going to unblock me ... it's just that that helps ... it's the only way to learn a language I think).

In reflecting on Annie's orientation to classroom language learning, it is also instructive to note that her instructor perceived her as a poor student who neither participated well in class nor seemed particularly interested in learning English. Commenting on her attendance Ms. Bruno described her as "a person who either comes in late or leaves early." In terms of how Annie herself evaluated her progress in English outside class, the review was more favorable: "mais là je m'améliore ... mais ça sort assez bien; des fois c'est juste mes temps de verbes qui ne sortent pas bien, mais ça je pense que c'est normal un peu, mais d'habitude ça sort assez bien" (but I'm improving ... but it's coming out well; sometimes it's, it's just my verb tenses which don't come out well, but that, I think that's normal a bit, but usually it comes out OK).

Case 2 Julie: Task and perception of self as a language learner.

Julie's discussion of how she invested in the video project suggests how type of task can mediate a learner's perception of self as a language learner. Whereas the video project enhanced Julie's self-image as a successful language learner, another task, oral presentations, appeared to have had the opposite effect.

Reflecting generally on past English classes (an experience that included eight years of classes in elementary and high school), Julie characterized them as plate (boring) and trop thérique (too theoretical):

J'aime ça parler en anglais; je comprends l'anglais mais mes cours d'anglais, $j^{\prime}$ ai de la misère à m'y faire ... je ne sais pas pourquoi ... théorie, laboratoire, théorie, laboratoire, c'est toujours la même chose ... on est tanné. (I like to speak English; I understand English but my English courses, I have a tough time getting into them ... I don't know why ... theory, laboratory, theory, laboratory, it's always the same thing ... we've had it.)

When asked what she meant by theoretical, not only did she mention grammar, but also, rather surprisingly, oral presentations. For Julie the video project was a welcome change, which she described positively as "quelque chose de concret en dehors de la classe" (something concrete outside of class) and 
"une autre vision d'anglais" (a new vision of English). She also drew an analogy with her tourism classes where the projects could be somewhat unusual: "toujours des cours un peu flyés" (always courses a bit off-beat). Julie was pleased to announce that in Ms. Bruno's course she felt she had made tangible progress: "là j'ai trouvé cette fois-ci, j'ai l'impression que j'ai fait un bond dans mon anglais, c'était [level of the class] plus haut que d'habitude, depuis le primaire c'est toujours la même chose" (there this time I found, I had the impression that my English had made a leap, it [level of class] was higher than usual, since elementary school it's always the same thing).

During the interview Julie contrasted how proud she had been to present her video (which was on the Molson Centre, the home of the Montreal Canadians hockey team) in class with how awful she had felt doing oral presentations:

[during oral presentations] "souvent on est tellement nerveux, puis ... c'est pas bon, on est peut-être capable de parler anglais, mais on est tellement gêné ... on est tellement poigné en avant [in the editing room] là on était toutes seules, nous dans la salle de montage, donc notre prononciation était bonne selon nous ... on n'était pas gêné de parler dans le micro ... on sait qu'ils [the students] vont nous écouter mais on n'est pas devant eux ... moi, j'aime mieux parler comme ça ... mais là [in the video] ils voient notre anglais, notre vrai anglais ... notre vrai anglais ... [during oral presentations] ... mais tu es tellement nerveux, tu arrives en avant, tu garoches, ça c'est pas beau ... [in the video] je savais que j'avais bien parlé" ([during oral presentations] often you're so nervous, then ... it's not good, maybe you're able to speak in English, but you're so self-conscious ... you're trapped up front ... [in the editing room] there we were all alone, us in the editing room, so our pronunciation was good in our opinion ... we weren't self-conscious about speaking in the mike ... we know they [the students] are going to listen but we're not in front of them ... I prefer to speak like that ... there [in the video] they see our English, our true English ... our true English ... [during oral presentations] ... but you're so nervous, you get up front, you mess up, it's not nice ... [in the video] I knew I had spoken well.)

Unlike oral presentations, the finished video enabled Julie to present to her classmates an image of herself as an English speaker as she would like to be seen; she could show others her vrai anglais (true English). The importance she attached to presenting herself in a favorable light might be further appreciated by the fact that at several points she stressed she was a perfectionist. Julie's pride in her video was also evidenced by the fact that she had shown it to others outside of class, namely, her boyfriend and father. Furthermore, in recounting this anecdote Julie emphasized the latter's surprise at seeing her speak English, a comment that was framed by an earlier reminder 
of her reticence in speaking English: "Moi je suis gênée à parler en anglais devant les gens, moi je parle jamais en anglais ... on me dit 'mon Dieu, tu parles en anglais!'" (I'm self-conscious about speaking English in front of people, I never speak English ... they said 'my God, you speak English!'). For Julie speaking English was important. Indeed, at one point she stated "Nous, en français on est fier mais quand on parle l'anglais on est doublement fier" (speaking French makes us proud, speaking English makes us doubly proud). Although on the one hand Julie's comments attest to a desire to speak English, they also suggest how fragile may be her identity as a bilingual speaker.

Julie's deep investment in the video project was also reflected in the effort she put into creating the video artifact. In contrast to previous ESL courses, Julie confided that she had never spent so much time working on an English assignment. In producing her video Julie followed the process set out by the teacher. She collaborated closely with her partner on the proposal, videotaping, and editing of the video. When reading the documentation she had gathered, she stressed the care she had taken to make sure she had properly understood and said she had looked up words in the dictionary and had received help from her boyfriend. In order to ensure that there were no errors in their script, Julie said that she had revised and edited it four times: "on a changé tout le temps quelque chose, on a vu toutes nos erreurs" (we were continually changing things, we got all our errors). Julie confirmed that she had greatly appreciated Ms. Bruno's feedback and had also consulted her boyfriend. Before recording the voice-over, Julie had spent 30 minutes practicing with the monitor and also practiced an hour at home in front of a friend. As a result of the intense practice involved in preparing the script, Julie stressed that certain words were engraved in her memory.

During the interview, however, her partner, who was also present, revealed that, much to her regret, Julie had undertaken to write the script by herself. Although Julie protested that this had been because of time constraints and conceded that they could have divided the task, my impression was that her decision to do so was more related to her self-avowed perfectionism and her desire to get the best possible product. Rather than count on her partner, whose English was weaker than hers, Julie apparently preferred to consult more capable others. As for the final product, Julie proudly pointed out that, unlike some of the videos, they had done a good job lining up the images with the text (a point confirmed by Ms. Bruno). Ms. Bruno also considered their video to be among the best, particularly the quality of their text and the voice-over.

Case 3 Stéphanie: Task and attitude to group work.

Like Annie and Julie, Stéphanie had a positive orientation to learning English. Originally from France, Stéphanie had spent summers studying English in the United Kingdom and living with a host family there. At this 
point in her life Stéphanie, who at 31 was somewhat older than most of the other students, had a 10-year-old son who she said was already bilingual. She was aware of the importance of English for her career in tourism and wanted to improve. Stéphanie very much liked the video project and considered it a good way to learn English. However, as demonstrated below, despite her positive attitude both to English and to the task at hand, her dislike for group work detracted from her ability to take maximum advantage of the resources afforded her by the course.

In discussion with Stéphanie as to whether she got along with her partner Lucie, a clear preference for working alone rather than collaboratively with others became apparent. Far from valuing the potential for learning that such interaction might offer, she tended to view group work as evidence that students were not able to think for themselves:

Stéphanie: When there is something to do, they [the other students] can't think alone; the first thing they do is to ask-and you, what do you think about that?...

Stéphanie: (talking about other school projects) Because I made a lot of project, not a video project, but some other works-write a report or I don't know-and everything, every time, it was the same question. First of all, they ask-OK, you, what do you think? And you? They can't have their own idea, it's very, I don't know how to say-strange. Because they are 18 or 20 years old and they can't think by themselves, always they ask to others what they think, maybe it's in, I don't, how the school is here but

Interviewer: (checking) This is in your other courses too?

Stéphanie: Yes, yes.

Interviewer: Where you have to work in groups too?

Stéphanie: Yes, hmhm. And it was always the same question, first of all they ask, bon OK, you, what do you think? But they don't have their own idea, it's strange, I can't understand that, because students here can't think alone, and they can't write alone or, I don't know, it's very different way to work.

Interviewer: Do you prefer to work alone?

Stéphanie: Yes....

Stéphanie: I understand that they like this (working in groups), so I try and I hope they try too, but I know it's different ... because of the age and the culture and everything, it's different 
In reflecting on her attitude to group work, Stéphanie's comments bring to light cross-cultural differences in schooling and the way students are socialized into institutional practices. At the CEGEP where Stéphanie was enrolled, group work and projects were widely used not only in English classes, but in other courses as well. Many of the students who were interviewed remarked that they had previously worked with a partner on projects other than English. Although the way the Quebec students collaborated with their partners varied greatly, none expressed a preference for doing the project alone. In fact the one student who had worked alone due to scheduling constraints and a shortage of partners ultimately regretted having done so. Unlike her Quebec classmates whose previous schooling in elementary and high school had given them experiences in pair or group work, Stéphanie had been in a school system that valued individual work exclusively:

Stéphanie: In France when I was a student, we used to work alone, we we didn't make a lot of, how to say that?

\section{Interviewer: Projects?}

Stéphanie: (finding the word) In groups. We are, we had lot of works to do in literature or everything but alone, we used to work alone, so I used to take some decision you know, I said, ah this way it should be a good idea.

As Stéphanie pointed out, her schooling had habituated her to working alone and making her own decisions; her classmates' habit of seeking the opinion of others appeared to her as a weakness-the inability to think by themselves.

Although Stéphanie had been in Quebec for six years and was in her second year at the CEGEP, her desire to work alone appeared deeply ingrained. Summing up her reaction to the video project, Sylvie described it as a "great experience," except for one thing: "fine to do but I prefer to make alone." In analyzing her comments as to how she actually went about doing the project, what stood out was the lack of collaboration with others and her repeated attempts to get out of working with her partner. In talking about exchanges with Lucie, Stéphanie noted: "I let her talk but I do what I want, you can say what you want, but I will do what I want." When, for example, they were filming at their tourist site, the remains of a fort with a museum, and disagreed on the angles for the shots, Stéphanie suggested that Lucie should shoot the inside of the museum and she should do the outside, but each as she wished: "So I say shoot inside as you want, me I shoot outside as I want, and like this it will be OK." Although for the script it might have seemed more logical for each person to write the part she had filmed, they finished by doing the opposite in order to accommodate Lucie's desire to use 
information she had received from her brother about outdoor attractions on the grounds during summer.

Stéphanie's strategies for writing the script were generally positively viewed. Before writing she brainstormed, wrote a draft, then after a two-day interval revised it; indeed, the draft in her portfolio provided evidence of numerous changes. However, despite these good strategies, Stéphanie did not seek feedback from others. She and her partner worked separately and merely exchanged copies of their work without giving each other comments. In addition, she neither received feedback from Ms. Bruno on her script, nor practiced the voice-over with her or a monitor (although she practiced by herself at home with the video). As for the finished product, although Stéphanie was quite pleased with it, had shown it to her son, and said she intended to keep it, Ms. Bruno considered it to be one of the weaker projects, noting problems at a technical level (e.g., lining up text and images) as well as grammar mistakes. As Ms. Bruno observed, Stéphanie did not "respect the process" that she had attempted to map out to enable students to achieve a more polished product.

Thus despite the availability of certain resources, Stéphanie did not appear to value how others could enhance the quality of her work. Although she worked hard, her preference for working alone predominated throughout the entire project; opportunities for collaboration with othersher partner, the instructor, the monitor-were sidestepped again and again. Unlike many of the students in the project who collaborated in productive ways and even involved others outside the school, Stéphanie relied solely on her own resources.

\section{Discussion}

Following the above descriptive accounts of the three case study participants (Annie, Julie, and Stéphanie), I now focus more specifically on how the interpretive framework provided by activity theory may account for the participants' differential investment in the video project. As predicated by activity theory, the motives that underlie why individuals engage in activities influence how goals are subsequently formulated; a given goal can be operationalized by a variety of actions (i.e., the specific mediational means or strategies selected to carry it out). To understand the pathways navigated by individuals as they engage in activities requires both a foregrounding of personal histories and a consideration of the setting where the activities take place.

Although all the case study participants completed the video project, Table 1 reveals differences in how they accomplished this task with respect to motive and the implementation of goal or actions. All participants were positively oriented toward the learning of English; however, differences emerged concerning their motives for engaging in the video project, per- 
Table 1

Comparison of how Three Participants Invested in the Video Project Based on Levels of Analysis Drawn from Activity Theory

\begin{tabular}{|c|c|c|}
\hline Participant & Activity/Motive & Goals/Actions \\
\hline Annie & $\begin{array}{l}\text { - positive orientation to ESL } \\
\text { learning } \\
\text { pegative orientation to video } \\
\text { project (main objective: dispense } \\
\text { with course requirement) }\end{array}$ & $\begin{array}{l}\text { - divided up tasks based on criterion of } \\
\text { efficiency (who could do the easiest) } \\
\text { - did not revise the proposal (even though } \\
\text { required) } \\
\text { - wrote script in French and had translated } \\
\text { by friends (nothing learned) } \\
\text { - did not record a part of the voice-over } \\
\text { (even though required) } \\
\text { - memorized text written by partner to } \\
\text { present video in class }\end{array}$ \\
\hline Stéphanie & $\begin{array}{l}\text { - positive orientation to ESL } \\
\text { learning } \\
\text { - positive orientation to project } \\
\text { (perceived as opportunity to learn } \\
\text { English) }\end{array}$ & $\begin{array}{l}\text { - prefered individual work; strategies aimed } \\
\text { at avoiding group work } \\
\text { - during filming no collaboration with partner } \\
\text { (each worked separately) } \\
\text { - gave partner a copy of her part of the } \\
\text { script but no discussion } \\
\text { - evidence of strategies for editing and } \\
\text { revising script, but did not seek out } \\
\text { feedback from others (e.g., partner, } \\
\text { teacher, monitor), even though required } \\
\text { - practiced pronunciation at home, but did } \\
\text { not visit monitor (even though required) }\end{array}$ \\
\hline Julie & $\begin{array}{l}\text { - positive orientation to ESL } \\
\text { learning } \\
\text { - positive orientation to project } \\
\text { (perceived as opportunity to learn } \\
\text { English) }\end{array}$ & $\begin{array}{l}\text { - considered she worked harder on this } \\
\text { project than any previous English } \\
\text { assignment } \\
\text { - basically followed procedures suggested } \\
\text { by teacher; collaborated } \\
\text { with partner (except on writing of script) } \\
\text { and got feedback from teacher, monitor, } \\
\text { and boyfriend } \\
\text { - revised/edited script } 4 \text { times to get rid of } \\
\text { all her errors } \\
\text { - ensured that images and script lined up } \\
\text { well } \\
\text { practiced voice-over with monitor and at } \\
\text { home with boyfriend }\end{array}$ \\
\hline
\end{tabular}

ceived either as the mere completion of a course requirement or as an opportunity to learn English. To carry out the project students had to formulate a number of goals pertaining to the various subtasks required to implement the project (videotaping the site, writing a proposal and a script, editing the video, doing the voice-over). The Goals/Actions column highlights the specific strategies selected by participants to carry out various goals. 
Of note with respect to Annie is that although she valued learning English and understood its use value (Gillette, 1994), she differentially invested in this activity depending on the social context. Thus the real world, with the opportunity to interact with native speakers, was viewed as the only place where true competence could develop; the classroom, negatively viewed, had little to offer. This orientation to classroom learning appears to have been fostered by the years spent in elementary and high school ESL classes that failed to help Annie develop a sense of being able to speak English. By contrast, her immersion experience in western Canada served, in her words, to unblock her English and create confidence in her ability to communicate in the language. The importance she accorded to this strategy for learning languages was further reflected in her decision to go abroad to improve her Spanish.

Annie's orientation to classroom learning appears to have played a decisive role in how she oriented herself to the video project and the strategies used to carry it out. As Annie perceived the video project merely as a course requirement with little or no relevance for helping her improve her English, the need for efficiency predominated: getting the job done. Tasks were thus divided based on who could do them most readily. In sociocultural theory, school and workplace settings have been associated with privileging two distinct motives: learning and productivity/efficiency, respectively (Dias, Freedman, Medway, \& Paré, 1999; Parks, in press; Wertsch, Minick, \& Arns, 1984). As Annie freely acknowledged, the video project contributed little or nothing to helping her perfect her English; in other words, the learning outcomes (or lack thereof) were directly influenced by the motive privileged and the strategies subsequently used to carry out the task. In the case of the video project, Annie's orientation to the task was more consistent with its construct as work than as an opportunity for learning.

In contrast to Annie, Stéphanie both valued learning English and considered the video project to be an interesting and useful task to this end. However, in terms of understanding the strategies she subsequently used to carry out the project, an important factor was her preference for individual as opposed to group work. Although the task as specified by the instructor was intended to foster collaborative activity, prominent were her efforts to negotiate herself out of work with her partner and her failure to avail herself of certain resources (e.g., feedback from the instructor and the monitor). In other words, the "scaffolding" that the instructor had attempted to build into the task-the task blueprint-was, due to Stéphanie's individualistic stance, systematically sidestepped, thus precluding opportunities for producing a (potentially) more polished product.

In view of the importance generally accorded to teamwork at the CEGEP where Stéphanie was enrolled, her resistance to it is particularly striking. As 
she explained, her desire to avoid such projects extended not only to the ESL video project, but to a video project for another course, as well as other types of projects. As to why she so strongly resisted group work, Stéphanie herself evoked the influence of her schooling in France, which, unlike the Quebec school system, emphasized individual work exclusively. Although advocates of strategy use and learning styles tend to discuss these as attributes of the individual, what McCarthey (1998) refers to as the "essentializing self," a more socioculturally oriented perspective suggests the powerful socializing effects of specific literacy practices (Angélil-Carter, 1977; Maguire, 1994; Parks \& Maguire, 1999; Wertsch, 1998). However, in addition to the socializing effect of schooling, Stéphanie also points to her age as another possible reason. In discussing how her younger classmates engaged in group work, she was quick to characterize their exchanges as evidence of their inability to think; by contrast, she portrayed herself as having the skills that enabled independent action. It may be that her willingness to continue to invest in an individualistic approach to learning facilitated her carving out of a more viable identity for herself, one that enabled her to put distance between herself and her younger classmates.

In applied linguistics one line of research on strategies (Oxford, 1990) situated in a cognitive / psycholinguistic perspective has given rise to a number of taxonomies and questionnaires intended to classify learners as good or poor in relation to the types of strategies characteristically used. Despite the insights provided by such research, representing strategies as reified attributes of the individual tends to distort and obscure the complex ways strategies are appropriated or resisted in concrete, socially embedded activity. As Gillette (1994) has demonstrated, effective strategy use in the L2 classroom may be mediated by the learners' original motive for taking the course; students who were positively oriented to the course tended to use effective strategies; those who were merely taking the course for credit and were not sensitive to the use value of language learning tended to be ineffective strategy users, even in instances where instruction in strategies had been given. With respect to Gillette's study, the case of Annie introduces a caveat, namely, that a generally positive orientation to language learning may not necessarily result in effective in-class use of strategies. As discussed above, Annie's negative view of the value of classroom L2 learning mediated how she invested in the video project. In this instance her use of translation, failure to take advantage of opportunities to practice (e.g., doing the voiceover or rewriting the proposal), and general lack of investment in the task are reflective of the types of strategies typically associated with poor language learners (Gillette, 1994).

Beyond this caveat, however, Annie's case is consistent with one of the main tenets of activity theory, which pertains to how sociocultural setting relates to motive and the implementation of goals/actions. The poor lan- 
guage learning strategies that in the classroom context appear to cast Annie as an ineffective language learner contrast with those more positive strategies that she employs outside the classroom (in particular her willingness to seek native speakers). As to how activity setting may be implicated in strategy use, it is of note that in the context of the interview, which took place in her school and where I presented myself as an ESL teacher/researcher, Annie opted to speak in French, not English. As in her interview she had stressed her use of English with friends, it may be that this particular situation, even though I had greeted her in English and spoke English throughout, was still too threatening for her. Studies (Norton, 1997; Peirce, 1995) conducted in the framework of investment theory have similarly associated willingness to speak in the L2 with place and the way identities are engaged.

As the mixed results of instruction in strategy use suggest, knowledge of strategies does not guarantee their use or their use in an effective manner (Gillette, 1994). Consistent with activity theory and other socioculturally motivated studies (Angélil-Carter, 1997; Wertsch, 1998), Stéphanie's avoidance of group work is reflective of how mediational means may be variously appropriated or resisted. As discussed above, despite a school context that actively promoted collaborative projects, Stéphanie avoided such engagements. Her case further suggests how an overarching strategy may have a negative impact on other essentially positive strategies. Although Stéphanie demonstrated good strategy use in the way she edited and revised her drafts on her own, for example, she did not seek out feedback available to her from other sources such as the teacher or the monitor.

The case of Julie further shows how activity theory can be a useful interpretive framework to clarify how students differentially invest in tasks. Like Stéphanie, Julie was both positively oriented to learning English and appreciated the video project as a means to improve her English. However, unlike Stéphanie, she followed the process suggested by the teacher. In particular, she collaborated with her partner (with the exception of writing the script) and took advantage of the resources available to her in terms of the feedback provided by the monitor and the teacher. Indeed, from Julie's perspective, she had never worked so hard on an English assignment. However, it is of particular interest in the case of Julie how issues of identity mediated how she invested in specific L2 tasks (McKay \& Wong, 1996; Norton, 1997; Thesen, 1997).

In this regard, Julie contrasted the experience of doing the video project, which she viewed as empowering, with that of oral presentations. A key point in this regard pertains to how she perceived these tasks as enabling her to project to others an image of herself as, to use Bourdieu's (1977) apt term, a "legitimate speaker" of English. Whereas she perceived oral presentations as reflecting on her poorly, the video project enabled her to shine before her 
classmates, to show her vrai anglais (true English). For Julie the pride she took in doing the video project was further evidenced by her decision to show it to a friend and her father. Recalling their comments, Julie emphasized that they had complimented her on her English. The link that Julie made between the video project and a positive self-image of herself as a language learner brings to mind Bakhtin's (1981) insights into how our self-consciousness is formed by being mirrored through the eyes of others. The importance that Julie appeared to give to how she was perceived by others may also have been reinforced by her self-avowed perfectionism. As a cultural tool the video enabled her to control the image of herself she wished others to see as the relative spontaneity of an oral presentation could not. The deep investment in this activity supports other studies that have linked investment in L2 tasks to issues of identity (McKay \& Wong, 1996; Thesen, 1997).

In discussing the lack of investment by US university students in foreign language study, Robbins (1998) suggests that the implicit message being conveyed in many classrooms is one of failure. To combat this Robbins has drawn attention to the need to create challenging tasks that engage students at an affective level and provide for a sense of empowerment. Drawing on Rommetveit's notion of prolepsis, Robbins stresses the need for pedagogical discourse that arouses in the learner an anticipation of success. For Stéphanie, and certainly for Julie, the video project would appear to have functioned at this level. By contrast, oral presentations in which students had to stand up in front of their classmates and recite memorized texts appeared to evoke not only in Julie, but also Annie and a number of the other students in the study a sense of disempowerment. Indeed, for Annie what stood out in her mind was the feeling of gêne (self-consciousness) that she and, according to her, her classmates experienced at such moments.

A further point that may influence how certain students invest or fail to invest in ESL classes in the Quebec context pertains to the broader socio-political discourse that exhorts francophones to uphold the French language and culture. Although a more detailed probing of Annie's views on this issue would have been useful, it is noteworthy that the gêne that she complained of during the class presentations was associated with the difficulty of speaking English in front of other francophones. Certainly one francophone teacher, Morrissette (1997), with 20 years experience teaching ESL in the Quebec school system, has identified résistance politique as one reason why some francophone students have particular difficulty learning English "la langue de "l'envahisseur", celle qui menace non seulement notre langue, mais aussi notre culture au Québec" (the language of the "conqueror," that which threatens not only our language, but also our culture in Quebec, p. 25).

Indeed, the way individual utterances, to use Bakhtin's expression, "ventriloquate" social discourse appears particularly striking in Julie's assertion that "nous, en français on est fier mais quand on parle l'anglais on est 
doublement fier (speaking French makes us proud, speaking English makes us doubly proud). In Quebec the term fierté (pride) challenges the widely circulated ideal of taking pride in speaking French. Julie's utterance, which evokes pride in speaking both languages, may suggest how she has repositioned herself in the dominant discourse in order to pursue her ambition to learn English. For teachers and teacher educators in Quebec a major objective must be to foster pedagogical approaches that enable students to develop positive images of themselves as speakers of both French and English-to be, as Julie put it, doublement fier (doubly proud).

More specifically, with respect to project-based and cross-curricular teaching, I would like to propose that the following points be given consideration: (a) reflective analysis of task and process, and (b) cross-curricular initiatives with content-teacher involvement.

Reflective analysis of task and process. Although for the video project students were asked to keep logs, entries tended to deal with the logistics of carrying out the tasks. To move beyond superficial reporting, students could be asked to reflect more specifically as to how the strategies used contributed or failed to contribute to a satisfactory outcome. Entries could also deal with an analysis of the group dynamics. How does the individual perceive his or her contribution in relation to carrying out the task successfully? What difficulties were encountered? What solutions might be envisaged? In addition to enhancing student awareness as to their preferences for strategy use and functioning in groups, such entries could also serve to inform teachers of orientations to learning that might otherwise go unnoticed or be misconstrued. Depending on their particular contexts, teachers may opt to confer with individual students or teams or engage the class in a more general discussion as to how to resolve various problems that may arise. With such a mechanism in place, it may have been possible, for example, to encourage Stéphanie to try out the socially oriented strategies she tended to avoid and/or to bring about a more positive relationship with her partner-someone whom she let talk but paid no attention to. In the case of Annie, as she valued more highly contact with English speakers, it may have been possible to adapt the project so as to include interviews (in English) with those involved in the tourism industry. Although in the literature on cooperative learning (Johnson \& Johnson, 1989), recourse to overt reflective analysis to assess interpersonal skills and strategy use has a well-established tradition, such is not the case in second-language teaching. As well, when adults or students from different cultural traditions are involved, it is important to engage the latter in understanding how past experiences may mediate current stances to pedagogical tasks.

Cross-curricular initiatives with the involvement of the content teacher. In the present study most of the students interviewed, including Annie, agreed that content related to tourism and learning how to make a video were positive 
features. Although the video project was time-consuming, a number of students nonetheless indicated that, if given the choice, they would prefer to do this assignment rather than a presentation in front of the class. The case of Julie further demonstrates how both the format of an activity and its link with a content course may engage language learners' emerging identities as legitimate speakers of the second language. Such positive comments on the part of the students support recent trends in ESL teaching that have underscored the importance of content-based teaching (Brinton, Snow, \& Wesche, 1989; Kasper, 1997, 1999; Krueger \& Ryan, 1993). However, in the varied course formats that may be ranked under this umbrella term, there is, in my opinion, a fundamental dividing line in terms of whether the ESL course merely draws on thematic content but is essentially given in parallel, or whether the ESL and content teacher work in tandem on joint projects (as, for example, in some adjunct courses). From the perspective of activity theory the latter option is particularly powerful as it provides a more meaningful interface between the ESL course and the student's desired professional orientation (i.e., between motive and object of study). From a language perspective it also favors greater use of authentic disciplinary genres rather than the pseudo-genres that are often featured in more traditional ESP textbooks.

Although recent attempts at disciplinary collaboration have pointed to the positive benefits for students, implementation of such projects has been far from easy. One difficulty, especially at levels of higher education, pertains to an educational culture that traditionally has not favored cross-curricular initiatives. Indeed, at the Institut de tourisme et d'hôtellerie du Québec, ESL teachers have over the years made numerous attempts to collaborate with disciplinary colleagues. However, even in the case of colleagues disposed to collaborate, initiatives may be thwarted by such administrative exigencies as course scheduling and budget constraints. ${ }^{7}$ Thus although the official Quebec Ministry of Education curriculum for the ESL CEGEP program stipulates courses that are intended to initiate students into disciplinary relevant genres, the historically entrenched administrative and educational cultures may undermine such initiatives. In such contexts ESL teachers are forced to carve out a pedagogical space in the disciplinary and administrative interstices that may be less than ideal for attaining goals of developing disciplinary specific language abilities.

\section{Conclusion}

In this article I discuss how three students enrolled in an ESP tourism course differentially invested in a video production task. I further suggest how activity theory, in conjunction with the construct of investment, provides for a robust theoretical framework by which to account for such differences. Although tasks as specified by teachers may set forth blueprints for pedagog- 
ical action, the socioculturally embeddedness of the tasks and how learners orient to these tasks based on their previous experiences may result in substantially different activities as to processes and outcomes. As illustrated by the cases of Annie, Julie, and Stéphanie, how learners invest in tasks also brings to the fore issues of identity and how stategies may be variously appropriated or resisted in particular settings.

Unlike traditional discussions of task conducted in the psycholinguistic/cognitive paradigm of SLA research, the present study dealt with a more substantive task or project involving the production of a video. As noted by Skehan (1998), more research on tasks needs to be conducted in real classroom contexts. However, as suggested here, a broader range of tasks should be analyzed with particular attention to the sociocultural dimension of task performance. As well, the viability of activity theory as a framework for accounting for differential investment in tasks and the varied outcomes in terms of processes and products needs to be further explored.

\section{Notes}

${ }^{1}$ In the province of Quebec, following high school, which goes to secondary 5 (grade 11), students who wish to continue their education move on to CEGEP, where students opt for either a two-year preuniversity program or a three-year professional program that prepares them for the job market, but also allows them access to university.

${ }^{2}$ For more recent versions of activity theory, see Cole and Engestrom (1993) and Russell (1997).

${ }^{3}$ Foley (1990) discusses how the Vygotskian construct of regulation offers a compelling framework for more fully understanding some of the principles underlying task-based approaches to second-language teaching, notably with respect to the emphasis placed on learning processes. However, this article does not deal with activity theory per se, nor does it address broader sociocultural issues related to the way learners invest or fail to invest in tasks, as discussed herein.

${ }^{4}$ In the spirit of intertextual play, the title of this article resonates with that of the Coughlin and Duff (1994) article entitled "Same Task, Different Activities: Analysis of SLA Task from an Activity Theory Perspective."

${ }^{5}$ The instructor wished for both herself and the school to be identified. Pseudonyms are used for other participants.

${ }^{6}$ The adjective gêné may be variously translated into English as shy, embarrassed, self-conscious. Although to facilitate reading I have selected one of these possibilities, self-conscious, the word gêne resonates differently in French than any one of several possible translations in English. It is also interesting to note that in French gêne has as one of its associated meanings sujétion (as in the dictionary entry from Le Petit Robert: Embarras, ennui, incommodité, sujétion). Through this association, gêne is thus linked to etymological derivations for sujétion pertaining to sujet (subject) and the Latin subjectio (soumission, submission).

${ }^{7}$ One of the most innovative attempts at content-based teaching was implemented by Ms. Bruno in the context of a course for restaurant service students. As students traditionally practiced their restaurant service skills in the Institute's two dining rooms, Ms. Bruno arranged for days when the guests would speak English (as typically most of the guests who dined at the Institute spoke French). To do this Ms. Bruno had to mount a campaign in order to attract English-speakers. The initiative was extremely successful to the extent that it was featured on $\mathrm{CBC}$ television news clips locally (Citybeat on Nerustuatch, November 23, 1992) and nationally (during December 1992), and 
in Josh Freed's (1992) Saturday column in The Gazette. The initiative stands out as an example of a course where students were truly engaged in the use of genre-specific language in an appropriate social setting. As students knew that they would be required to do their service in English, their motivation to learn the language presented in class was enhanced. Guests were also called on to fill out small evaluation forms as an indication of students' ability to communicate appropriately. Despite the extensive time and energy that Ms. Bruno put into setting up the infrastructure (e.g., address lists) and negotiating a mode of functioning with the restaurant service personnel, the project foundered when the administration, due to financial cutbacks, was unwilling to allocate money to pay for an ESL instructor to supervise students in the dining room as an official part of his or her task. Although the administration maintained that students would continue to practice in the dining rooms in English, this did not prove to be the case. Without the attention to attracting English-speaking guests who would be willing to speak English in a social context where under normal circumstances most would opt to speak French due to the Québécois context, the clientele dissipated. By inviting English speakers to participate in an educational event, Ms. Bruno had essentially redefined the motive-object of the activity setting. Not only were the English-speaking guests (including bilingual francophones who also felt free to try out their English) delighted with the experience, but individuals who had previously never set foot in the Institute suddenly began making reservations.

\section{Acknowledgments}

I would like to thank Diana Bruno for her collaboration during all phases of this study as well as comments on various drafts of this article. I would also like to thank the TESL Canada Journal's anonymous reviewers for their useful suggestions.

\section{The Author}

Susan Parks is an assistant professor at Université Laval, Quebec City, where she teaches undergraduate courses in the ESL teacher education program and graduate courses in applied linguistics. Her research primarily focuses on second-language literacy in school and workplace contexts.

\section{References}

Angélil-Carter, S. (1997). Second language acquisition of spoken and written English: Acquiring the skeptron. TESOL Quarterly, 31, 263-287.

Bakhtin, M.M. (1981). The dialogic imagination (M. Holquist, Ed., C. Emerson \& M. Holquist, Trans.). Austin, TX: University of Texas Press.

Bourdieu, P. (1977). The economics of linguistic exchanges. Social Science Information, 16, 645-668.

Brinton, D.M., Snow, M.A., \& Wesche, M.B. (1989). Content-based language instruction. New York: Newbury House/Harper \& Row.

Chaudron, G. (1988). Second language classrooms: Research on teaching and learning. New York: Cambridge University Press.

Cole, M., \& Engestrom, Y. (1993). A cultural-historical approach to distrbuted cognition. In G. Salomon (Ed.), Distributed cognitions: Psychological and educational considerations (pp. 1-46). New York: Cambridge University Press.

Coughlin, P., \& Duff, P. (1994). Same task, different activities: Analysis of SLA task from an activity theory perspective. In P. Lantolf \& G. Appel (Eds.), Vygotskian approaches to second language research (pp.173-191). Norwood, NJ: Ablex.

Crookes, G., \& Gass, S. (Eds.). (1993). Tasks and language learning: Integrating theory and practice. Clevedon, UK: Multilingual Matters.

Dias, P., Freedman, A., Medway, P., \& Paré, A. (1999). Worlds apart: Acting and writing in academic and workplace contexts. Mahwah, NJ: Erlbaum. 
Foley, J. (1990). A psycholinguistic framework for task-based approaches to language teaching. Applied Lingiustics, 11, 62-75.

Foster, P. (1998). A classroom perspective on the negotiation of meaning. Applied Linguistics, $19,1-23$.

Gillette, B. (1994). The role of learner goals in L2 success. In P. Lantolf \& G. Appel (Eds.), Vygotskian approaches to second language research (pp. 195-213). Norwood, NJ: Ablex.

Goldstein, T. (1997). Bilingual life in a multilingual high school classroom: Teaching and learning in Cantonese and English. Canadian Modern Language Review, 53, 356-372.

Johnson, D.W., \& Johnson, R.T. (1989). Leading the cooperative school. Edina, MN: Interaction Book.

Kasper, L.F.(1997). The impact of content-based instructional programs on the academic programs of ESL students. English for Specific Purposes, 16, 309-320.

Kasper, L.F. (Ed.). (1999). Content-based college ESL instruction. Mahwah, NJ: Erlbaum.

Krueger, M., \& Ryan, F. (Eds.). (1993). Language and content: Discipline- and content-based approaches to language study. Lexington, MA: DC Heath.

Lantolf, J., \& Pavlenko, A. (1998, March). Second language activity theory: Constructing whole learners. Paper presented at American Association of Applied Linguistics Conference, Seattle.

Maguire, M. (1994). Getting beyond programmes and instructional time in second-language teaching and learning: Who is mediating what? For whom? In what context? Journal of the CAAL, 16(1), 105-123.

Maguire,M. (1997). Shared and negotiated territories: The sociocultural embeddedness of children's acts of meaning. In M. Pollard, D. Thiessen, \& A. Filer (Eds.), Children and their curriculum. London, UK: Falmer Press.

McCarthey, S.J. (1998). Constructing multiple subjectivities in classroom literacy contexts. Research in the Teaching of English, 32, 126-160.

McKay, S.L., \& Wong, S.C. (1996). Multiple discourses, multiple identities: Investment and agency in second-language learning among Chinese adolescent immigrant students. Harvard Educational Review, 66, 577-607.

Merriam, S.B. (1988). Case study research in education: A qualitative approach. San Francisco, CA: Jossey-Bass.

Mohan, B., \& Smith, S.M. (1992). Context and cooperation in academic tasks. In D. Nunan (Ed.), Collaborative language learning and teaching (pp. 81-89). Cambridge, MA: Cambridge University Press.

Morrissette, E. (1997). Croyances et préjugés sur l'apprentissage d'une langue seconde. SPEAQ Out, 25(1), 25.

Newman, D., Griffin, P., \& Cole, M. (1989). The construction zone: Working for cognitive change in school. New York: Cambridge University Press.

Norton, B. (1997). Language, identity, and the ownership of English. TESOL Quarterly, 31, 409-429.

Oxford, R. (1990). Language learning strategies: What every teacher should know. Boston, MA: Heinle \& Heinle.

Parks, S. (in press). Professional writing and the role of incidental collaboration: Evidence from a medical setting. Journal of Second Language Writing.

Parks, S., \& Maguire, M. (1999). Coping with on-the-job writing in ESL: A constructivistsemiotic perspective. Language Learning. 49, 143-175.

Peirce, B.N. (1995). Social identity, investment, and language learning. TESOL Quarterly, 29, 9-31.

Roebuck, R. (1998). Reading and recall in L1 and L2. Stamford, CT: Ablex.

Robbins, D. (1998, March). A.A. Leontiev, Russian psycholinguistics, SLA classroom. Paper presented at American Association of Applied Linguistics Conference, Seattle. 
Russell, D. (1997). Rethinking genre in school and society: An activity theory analysis. Written Communication, 14, 504-554.

Schiffrin, D.(1996). Narrative as self-portrait: Sociolinguistic constructions of identity. Language in Society, 25, 167-203.

Skehan, P. (1998). Task-based instruction. Annual Review of Applied Linguistics, 18, 243-286.

Thesen, L. (1997). Voices, discourse, and transition: In search of new categories in EAP. TESOL Quarterly, 31, 487-511.

Wertsch, J.V. (1985). Vygotsky and the social formation of mind. Cambridge, MA: Harvard University Press.

Wertsch, J.V. (1998). Mind as action. Oxford: Oxford University Press.

Wertsch, J.V., Minick, N., \& Arns, F.J. (1984). The creation of context in joint problem-solving. In B. Rogoff \& J. Lave (Eds.), Everyday cognition: Its development in social context (pp. 151-171). Cambridge, MA: Harvard University Press. 